\title{
$S$-Wave Refraction Survey of Alluvial Aggregate
}

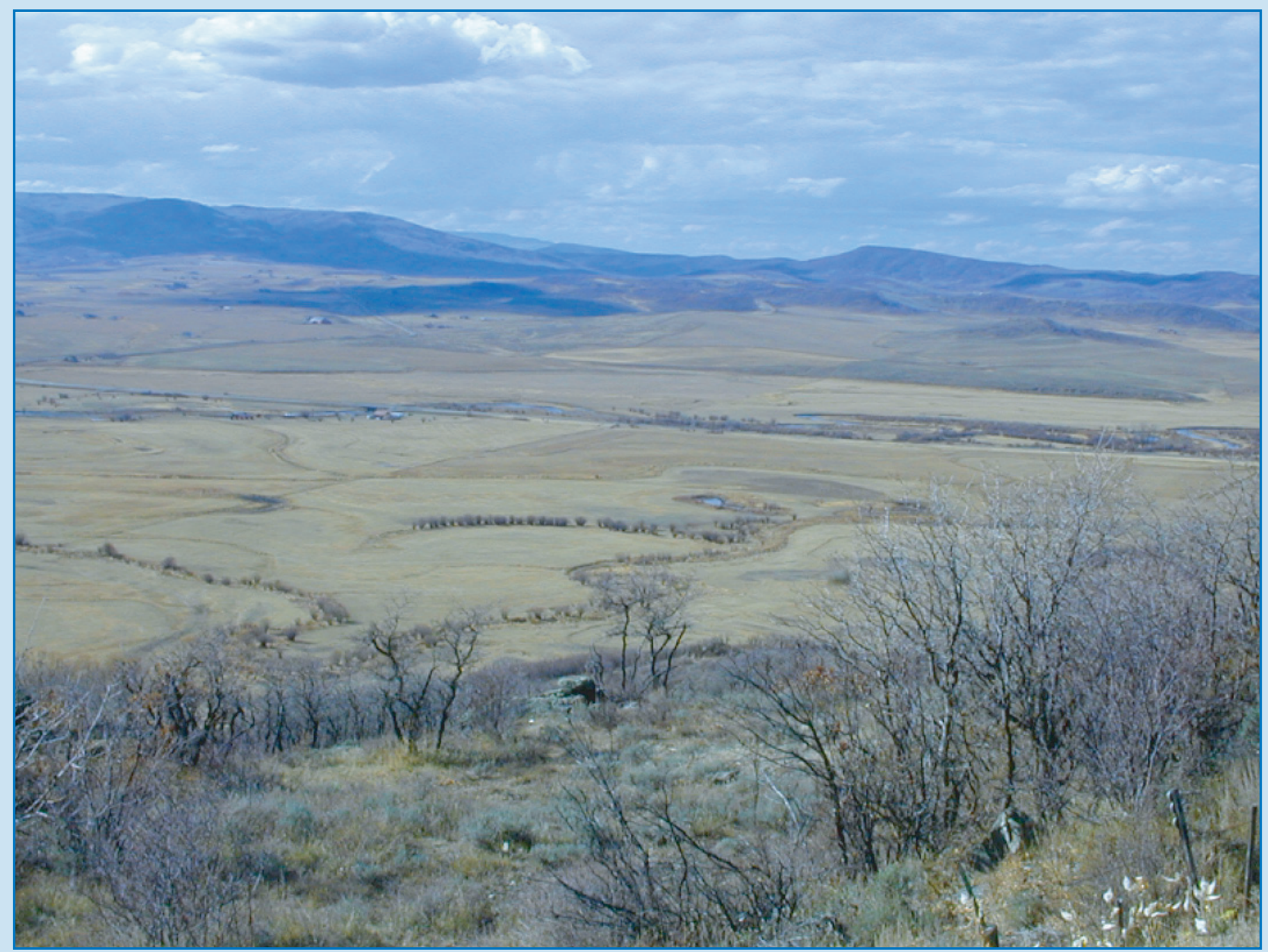

Scientific Investigations Report 2005-5012 


\section{$S$-Wave Refraction Survey of Alluvial Aggregate}

By Karl J. Ellefsen, Gary J. Tuttle, Jackie M. Williams, and Jeffrey E. Lucius

This survey was part of a Cooperative Research and Development Agreement between the U.S. Geological Survey and the Lafarge Corporation

Scientific Investigations Report 2005-5012 


\section{U.S. Department of the Interior \\ Gale A. Norton, Secretary \\ U.S. Geological Survey \\ Charles G. Groat, Director}

U.S. Geological Survey, Reston, Virginia: 2005

This publication is available online at URL:

http://pubs.usgs.gov/sir/2005/5012/

and as Scientific Investigations Report 2005-5012 on CD-ROM

For information on other USGS products and ordering information:

World Wide Web: http://www.usgs.gov/pubprod/

Telephone: 1-888-ASK-USGS

For more information on the USGS - the Federal source for science about the Earth, its natural and living resources, natural hazards, and the environment:

World Wide Web: http://www.usgs.gov/

Telephone: 1-888-ASK-USGS

Any use of trade, product, or firm names in this publication is for descriptive purposes only and does not imply endorsement by the U.S. Government.

Although this report is in the public domain, permission must be secured from the individual copyright owners to reproduce any copyrighted materials contained within this report. 


\section{Contents}

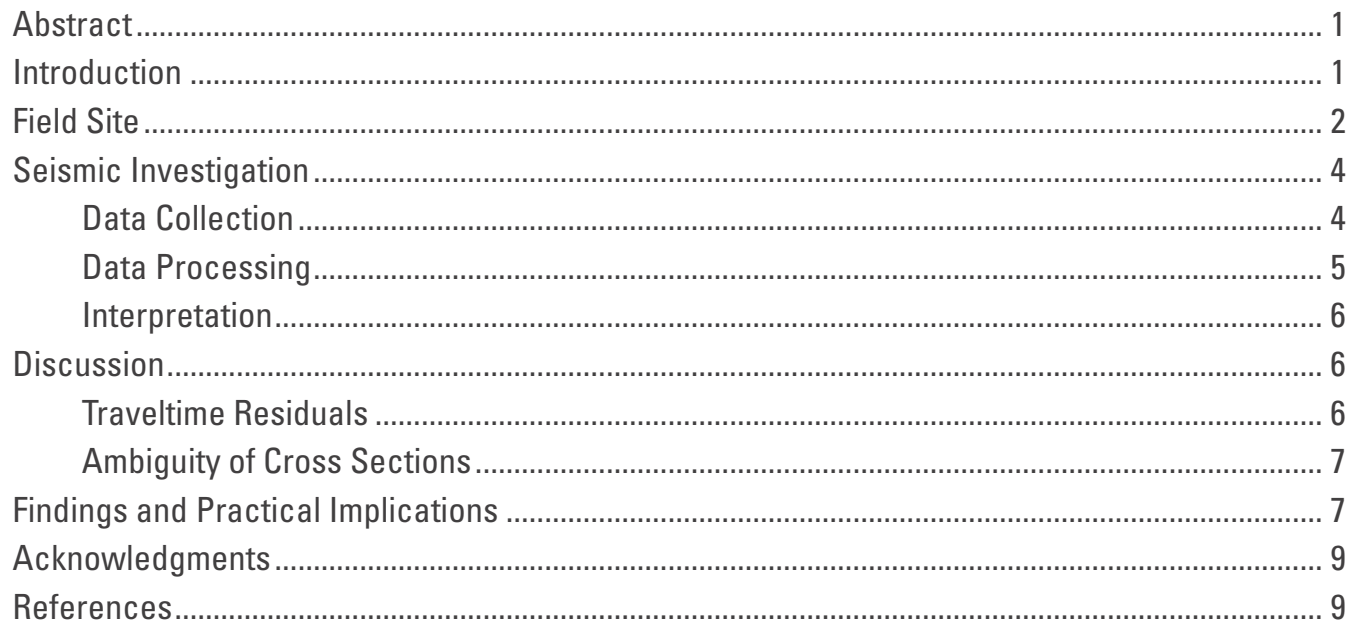

\section{Plates}

1. Aerial photograph of field site

2. Geologic logs for drill holes

3. Seismic cross sections for field site

\section{Figures}

1. Location of the field site and geology near the site ....................................................... 2

2. Photographs of view looking east along line $A A^{\prime}$, ditch used to irrigate the pasture, view looking south along line $\mathrm{BB}^{\prime}$.................................................. 3

3. Configuration of the spread used in 2001 and movement of the

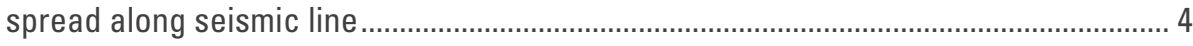

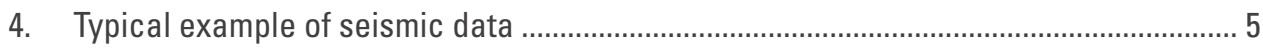

5. Diagram showing ambiguity in determining the thickness and the velocity of the alluvium ............................................................................................... 8

\section{Table}

1. Source and recording parameters used for the $S$-wave refraction survey 4 


\title{
$S$-Wave Refraction Survey of Alluvial Aggregate
}

\author{
By Karl J. Ellefsen, Gary J. Tuttle, Jackie M. Williams, and Jeffrey E. Lucius
}

\section{Abstract}

An $S$-wave refraction survey was conducted in the Yampa River valley near Steamboat Springs, Colo., to determine how well this method could map alluvium, a major source of construction aggregate. At the field site, about $1 \mathrm{~m}$ of soil overlaid $8 \mathrm{~m}$ of alluvium that, in turn, overlaid sedimentary bedrock. The traveltimes of the direct and refracted $S$-waves were used to construct velocity cross sections whose various regions were directly related to the soil, alluvium, and bedrock. The cross sections were constrained to match geologic logs that were developed from drill-hole data. This constraint minimized the ambiguity in estimates of the thickness and the velocity of the alluvium, an ambiguity that is inherent to the $S$-wave refraction method. In the cross sections, the estimated $S$-wave velocity of the alluvium changed in the horizontal direction, and these changes were attributed to changes in composition of the alluvium. The estimated $S$-wave velocity of the alluvium was practically constant in the vertical direction, indicating that the fine layering observed in the geologic logs could not be detected. The $S$-wave refraction survey, in conjunction with independent information such as geologic logs, was found to be suitable for mapping the thickness of the alluvium.

\section{Introduction}

Before a sand and gravel mine is opened in a new area, the sediment is usually drilled to determine whether it is suitable for aggregate and whether enough can be extracted to make the mine profitable. However, sometimes drilling is difficult because of the geology. For example, if the ground above a future mine is muddy or covered with water, then drilling trucks may be unable to reach every area that should be drilled. If the sediment for the future mine contains large boulders, the drill may hit a boulder and cause the driller to assume incorrectly that the drill has reached bedrock. Additional problems related to drilling are described by Timmons (1995).

For those situations where drilling causes problems, some of the needed geologic information may be obtained with a geophysical survey. Surveys of sediment deposits have involved many different geophysical methods, including airborne imagery (Singhroy and Barnett, 1984), airborne elec- tromagnetic profiling (Middleton, 1977), electrical resistivity sounding (Auton, 1992; Crimes and others, 1994; Jacobson, 1955; Middleton, 1977; Saarenketo and Maijala, 1994; Wilcox, 1944), frequency domain electromagnetic profiling (Auton, 1992; Middleton, 1977), $P$-wave refraction (Crimes and others, 1994; Middleton, 1977; Odum and Miller, 1988; Saarenketo and Maijala, 1994), $S$-wave refraction (Barnett and Ellefsen, 2000; Ellefsen and Barnett, 2001), and ground-penetrating radar (Jol and others, 1998; Saarenketo and Maijala, 1994). Moreover, electrical resistivity sounding, time domain electromagnetic sounding, frequency domain electromagnetic profiling, and ground-penetrating radar were compared by Ellefsen and others $(1998,1999)$ to evaluate their suitability for characterizing sediments used for aggregate.

For characterizing shallow sediments, $S$-wave refraction has several distinct advantages over other geophysical methods. One advantage is that $S$-wave refraction usually has better spatial resolution than many other geophysical methods. In other words, it can detect details in the geology that many other methods cannot. Another advantage is that $S$-waves in shallow sediments behave practically identically in unsaturated and saturated zones (McLamore and others, 1978), whereas $P$-waves, electromagnetic waves, and electrical current do not. Consequently, $S$-wave refraction data are simpler to collect, process, and interpret than most other geophysical data. Finally, clays, which are often prevalent in soils and depositional lenses within sediments, generally affect $S$-waves less than they affect electrical conductivity. Thus, where there is a large amount of clay, $S$-wave refraction is more likely to work than, for example, electrical resistivity sounding, time domain electromagnetic sounding, and ground-penetrating radar.

$S$-wave refraction is relatively new compared to other geophysical methods, and, consequently, it is used infrequently. Indeed, we believe that $S$-wave refraction has been used only once to characterize shallow sediments that could be mined for aggregate (Barnett and Ellefsen, 2000; Ellefsen and Barnett, 2001). This previous investigation was of a 9-km section of an alluvial valley with farms, ranches, and homes, and so the measurements were sparse. Moreover, the estimates of the depth to bedrock could be evaluated at only one locality where there had been some drilling. Because of the limitations of this investigation, a more thorough evaluation of $S$-wave refraction was deemed necessary. Consequently, a detailed $S$ wave refraction survey was conducted; this survey was part of a Cooperative Research and Development Agreement between the U.S. Geological Survey and the Lafarge Corporation. 


\section{Field Site}

The field site is located in the State of Colorado, about $12 \mathrm{~km}$ south of the town of Steamboat Springs, on the eastern side of the Yampa River valley (fig. 1). The geology in this and the surrounding area has been investigated by Kucera (1962), Buffler (1967), Tweto (1976), Snyder (1980), and Madole (1991); the description here relies primarily on the most recent investigations, which were by Snyder (1980) and Madole (1991).

At the field site (fig. 1), alluvium, which is of Holocene and late Pleistocene age, was deposited by the Yampa River. The alluvium consists of sand, silt, gravel, and minor amounts of clay. At two gravel pits north of the field site but within the same river valley, alluvial clasts are predominantly granitic rocks (36 and 41 percent), amphibolite (39 and 40 percent), and volcanic rocks (16 and 17 percent) (Madole, 1991). The alluvium overlies the Browns Park Formation, which is of Miocene age. (An exception may be in the southeast corner of the field site, where the alluvium may overlie other rocks of Tertiary age. However, seismic data were not collected in this corner, and so these rocks are not described.) The Browns Park Formation consists of siltstone, sandstone, conglomerate, and minor chert beds. The Browns Park Formation lies unconformably on three different rock units of Precambrian age: quartz monzonite, felsic gneiss to amphibolite metavolcanics, and pelitic schist. These Precambrian rocks crop out along the eastern edge of the field site.

In an aerial photograph of the field site (plate 1), the approximate edge of the alluvium is indicated by the yellow dashed line. East of this line are Precambrian rocks, which form a steep hillside that rises above the Yampa River valley (fig. 2A). The land on this hillside is undeveloped and is covered by small trees and bushes. West of the dotted line are
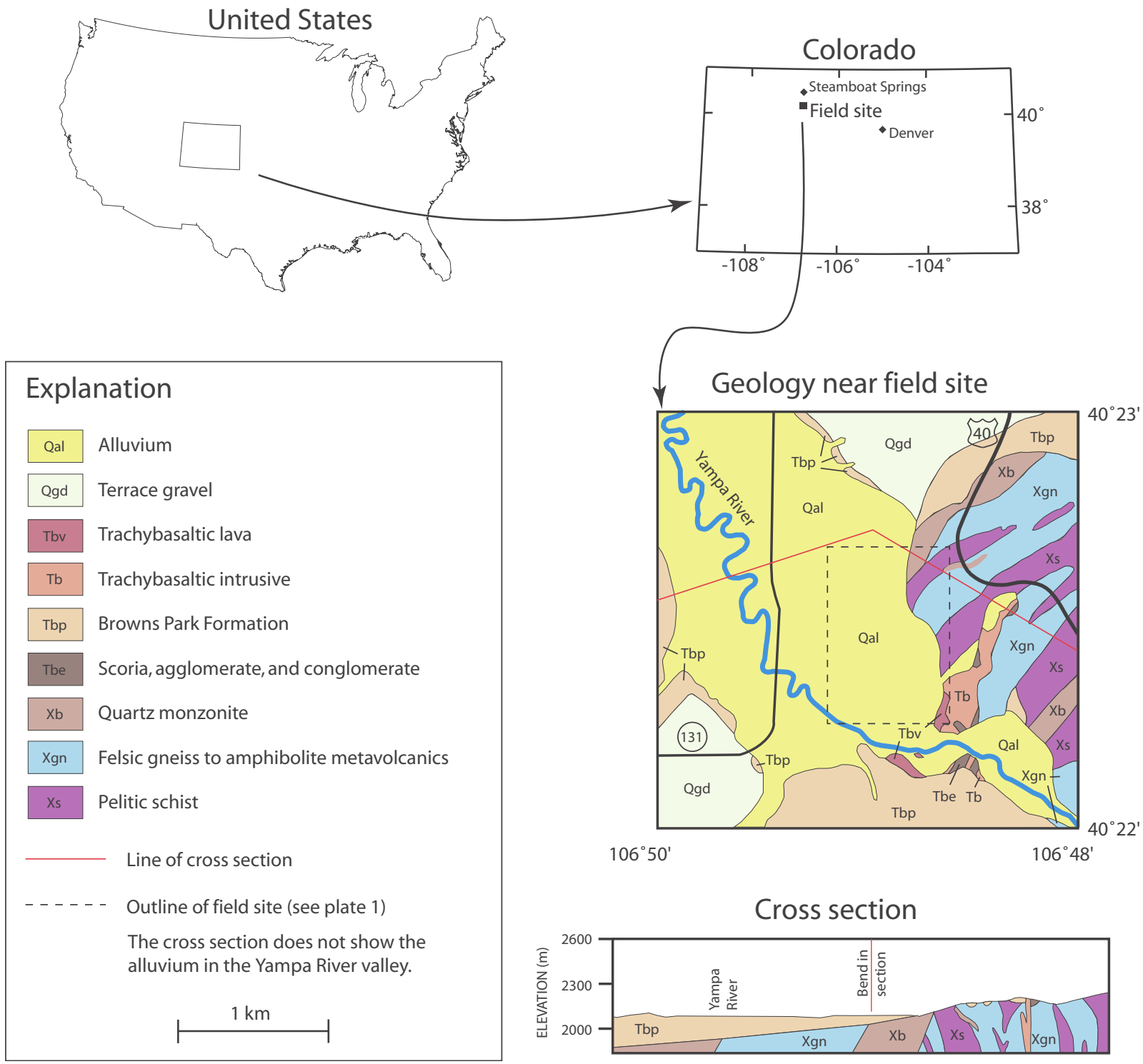

$106^{\circ} 50^{\prime}$

$106^{\circ} 48^{\prime}$

Cross section

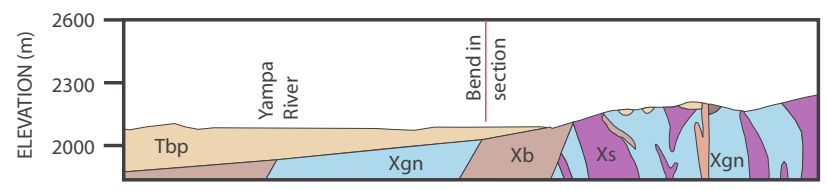

Figure 1. Location of the field site and geology near the site. Geologic map and cross section after Snyder (1980). 


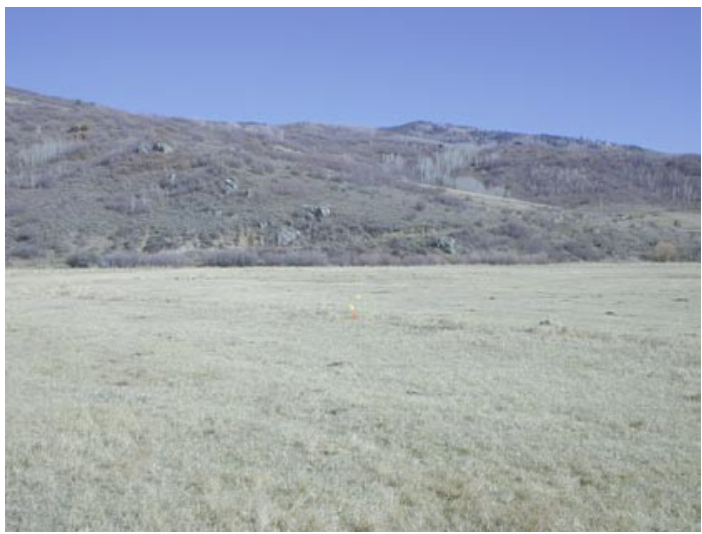

A

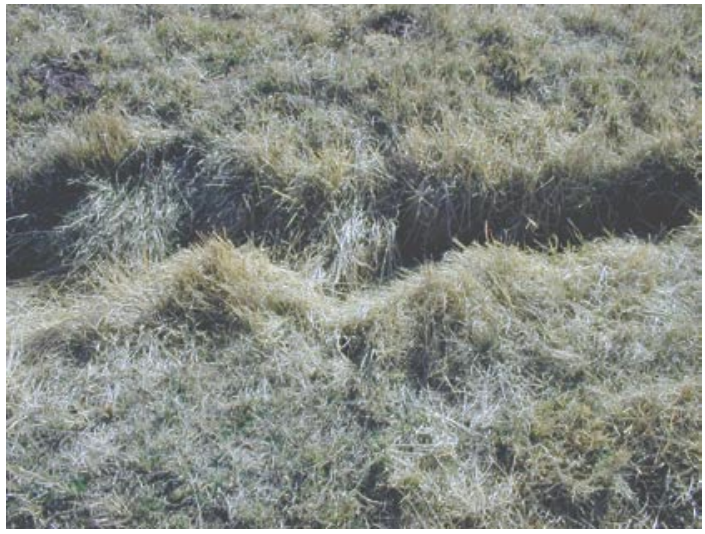

$B$

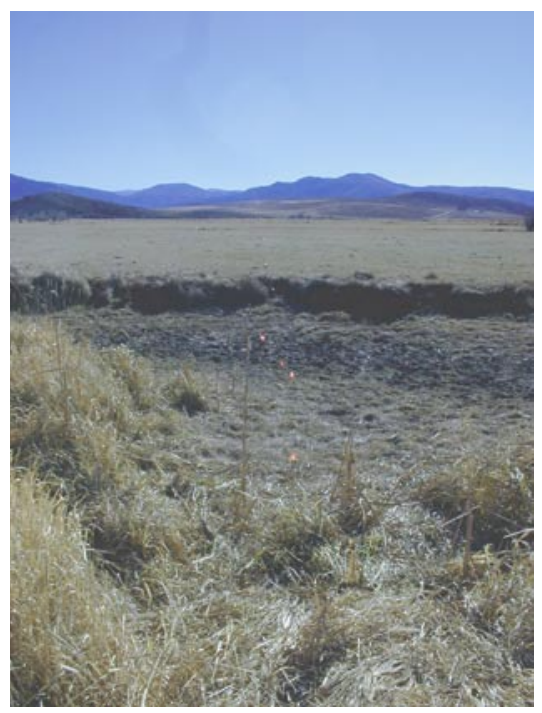

C

Figure 2. A, View looking east along line $A A^{\prime}$ (plate 1). In the foreground is pasture, which overlies alluvium. In the background is the hillside formed by Precambrian rocks. $B$, Ditch used to irrigate the pasture. $C$, View looking south along line BB' (plate 1). In the foreground is a former stream channel.

alluvium and the underlying Browns Park Formation. Here the land is flat and is currently used as pasture for cattle. The pastures are surrounded by barbed wire and are irrigated using small ditches (fig. 2B). The site is traversed by an abandoned stream channel, which is interpreted to be the ancestral Yampa River. The abandoned stream channel is lower than the surrounding land, and its bottom is mud (fig. $2 C$ ). When the water table is high, the abandoned channel is filled with water.

The alluvium was drilled by a private engineering company hired by the Lafarge Corporation. The company drilled 17 holes using an auger with a diameter of $10.2 \mathrm{~cm}$ (4 inches). Precise locations of the drill holes were not in the report provided by the engineering company; consequently, the locations of the drill holes shown on plate 1 are approximate, and the error in these locations may be as much as $50 \mathrm{~m}$. It is assumed that the drill cuttings were examined to determine the various geologic units because this information was not stated explicitly in the report. From these cuttings, geologic logs were developed and are reproduced on plate 2. The top of each log corresponds to ground surface, the bottom to the depth at which drilling ceased. The logs are plotted according to depth, which is relative to the ground surface near the drill hole.

Except for drill hole 3 (plate 2), each geologic log shows three layers: topsoil, alluvium, and bedrock. The thickness of the topsoil ranges from 0.3 to $1.6 \mathrm{~m}$, and its median thickness is $0.8 \mathrm{~m}$. The thickness of the alluvium ranges from 6.1 to $9.1 \mathrm{~m}$, and its median thickness is $7.8 \mathrm{~m}$. The alluvium is subdivided according to the dominant particle size: silts and clays, sands, sands and gravels, and cobbles. The alluvium and the bedrock in these geologic logs correspond, respectively, to the Holocene-upper Pleistocene alluvium and the Browns Park Formation in the geologic map (fig. 1). The Browns Park Formation was reported as being "weathered to hard," which is assumed to mean that this formation varied from weathered to slightly weathered. In drill hole 3 , the auger intersected dense cobbles and then broke. Thus, the auger did not intersect bedrock, and so the bedrock layer is not in the geologic log. Furthermore, these dense cobbles are not reported in the geologic logs provided by the engineering company-thus, they are not in the geologic logs on plate 2 . 


\section{Seismic Investigation}

\section{Data Collection}

$S$-wave refraction surveys were conducted from 6 to 9 November 2001 and from 23 to 25 October 2002. For these surveys, $S_{\mathrm{h}}$-waves were generated by an $S$-wave source designed by Hasbrouck (1983). Using a sledgehammer weighing $9.1 \mathrm{~kg}$, the source was struck on one side, generating $S_{\mathrm{h}}$-waves with one polarity. Then the source was struck on the opposite side, generating $S_{\mathrm{h}}$-waves with opposite polarity. The waves were detected by geophones manufactured by Geospace, Inc., that were sensitive to the horizontal component of particle velocity. The geophones had a natural frequency of $10 \mathrm{~Hz}$, and their voltage sensitivity was almost constant from about $20 \mathrm{~Hz}$ to greater than $300 \mathrm{~Hz}$. The voltages from the geophones were recorded by a RAS-24 seismograph manufactured by Seistronix, Inc. This seismograph had 48 channels, and its analog-to-digital converter used 24 bits. The data were stored in the SEG-2 format (Subcommittee of the SEG Engineering and Groundwater Geophysics Committee, 1990).

The source and recording parameters are listed in table 1. A record length of $0.5 \mathrm{~s}$ was long enough to record all of the direct and refracted waves that were needed for the processing; nonetheless, in 2002 the duration was increased to $1.0 \mathrm{~s}$ simply to record the entire surface wave. A sample interval of $0.5 \mathrm{~ms}$ was short enough to record with high fidelity all of the waves-because the highest frequency in the data was about $100 \mathrm{~Hz}$, the corresponding period was $10 \mathrm{~ms}$ and was sampled 20 times. Lower frequencies were sampled even more. Because there was usually little ambient noise, filters were unnecessary, and two or three strikes of the source were enough. However, in a few instances, the wind was moderately strong, and five strikes of the source were necessary.

Table 1. Source and recording parameters used for the $S$-wave refraction survey.

\begin{tabular}{ll}
\hline \multicolumn{1}{c}{ Item } & \multicolumn{1}{c}{ Value } \\
\hline Record length & $0.5 \mathrm{~s}(2001)$ \\
& $1.0 \mathrm{~s}(2002)$ \\
Sample interval & $0.5 \mathrm{~ms}$ \\
Filters & None \\
Strikes of source & 2 or 3 (light wind) \\
& as many as 5 (moderate wind) \\
\hline
\end{tabular}

The spread used in 2001 consisted of 48 geophones spaced $1.5 \mathrm{~m}$ apart and five sources (fig. $3 A$ ). On either end, the two sources were 1.5 and $34.5 \mathrm{~m}$ from the closest geophone. With this spread configuration, alluvium and bedrock were adequately probed with seismic waves. The spread was moved along the seismic line such that the distance between the last geophone on the current spread and the first geophone on the next spread was $1.5 \mathrm{~m}$ (fig. $3 B$ ). With this movement of the spread, geophone coverage along the seismic line was both continuous and uniform. The spread used in 2002 was identical to that used in 2001 except for a slight change in the locations of the sources.

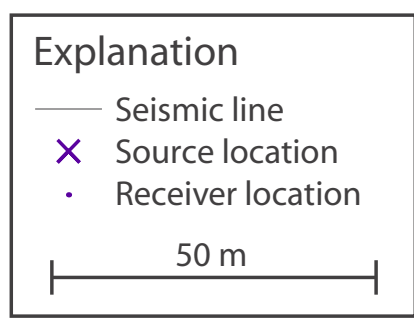

$\times$

$\times$
$\vdots$
$\vdots$
$\vdots$
$\vdots$
$\vdots$
$\vdots$
$\vdots$
$\vdots$
$\vdots$
$\vdots$
$\vdots$
$\vdots$
$\dot{x}$

Figure 3. A, Configuration of the spread used in 2001. $B$, Movement of the spread along seismic line. The first spread is colored blue; the second red.

Five seismic lines were used to investigate the field site, and they are labeled $\mathrm{AA}^{\prime}, \mathrm{BB}^{\prime}$, and so on (plate 1). Lines $\mathrm{AA}^{\prime}$ and $\mathrm{BB}^{\prime}$ were collected in 2001; lines $\mathrm{CC}^{\prime}$, $\mathrm{DD}^{\prime}$, and $\mathrm{EE}^{\prime}$ were collected in 2002. For those lines trending east-west, the first spread was on the eastern end, and the last spread on the western end. Hence, these spreads were numbered from east to west. For those lines trending north-south, the first spread was on the northern end, and the last spread on the southern 
end. Hence, these spreads were numbered from north to south. The eastern ends of lines $\mathrm{AA}^{\prime}$ and $\mathrm{CC}^{\prime}$ are near the boundary between the alluvium and Precambrian rocks. Lines $\mathrm{AA}^{\prime}, \mathrm{BB}^{\prime}$, and $\mathrm{DD}^{\prime}$ cross the former stream channel.

A typical example of the seismic data is shown in figure 4. These particular data were collected along the western end of seismic line $\mathrm{AA}^{\prime}$ (spread number A5). The source was at $104.7 \mathrm{~m}$ horizontal distance, just before the geophones. There are two sets of seismograms for the two polarities of the source. Between 104.7 and about 120 m horizontal distance, the wave that arrived first at the geophones was the direct wave that propagated through the soil and the underlying alluvium. Beyond about $120 \mathrm{~m}$ horizontal distance, the wave that arrived first at the geophones was refracted through bedrock. In addition to these two waves, there are also a Love wave, which is a type of surface wave, and another wave, which is between the refracted wave and the Love wave. This second wave is interpreted to be a leaky $S$-wave (Satô, 1952), which is analogous to the leaky modes in a layered acoustic medium (Aki and Richards, 1980, p. 319-335). This example shows that the record length of the seismograms ( $0.5 \mathrm{~s})$ was long enough to fully record the refracted wave and that the sample interval $(0.5 \mathrm{~ms})$ was small enough to record all waves with high fidelity.

For each spread, the locations of all sources and selected geophones were measured during a survey using an electronic total station instrument. These locations were in a threedimensional, Cartesian coordinate system, and the estimated maximum error in any location was about $5 \mathrm{~cm}$.

\section{Data Processing}

For each seismic line, a Cartesian coordinate system was selected. For those lines trending east-west, the origin of the coordinate system was on the western end of the line; for those lines trending north-south, the origin was on the southern end. Each coordinate system was oriented so that its $z$ axis corresponded to elevation, its $x$ axis corresponded to horizontal distance along the line, and its $y$ axis was chosen to make the coordinate system right-handed. For each seismic line, the locations of all sources and all geophones were calculated from the locations measured during the survey. The calculated $y$ coordinates were usually less than $0.5 \mathrm{~m}$, and this result indicates that the seismic lines were practically straight.

The time at which the direct or the refracted wave arrives at a geophone is defined as the traveltime, and some examples of traveltimes are shown in figure 4 . The traveltimes for all seismograms were picked manually and are displayed on plate 3. Although the arrival of the direct or the refracted wave is usually obvious, sometimes it is not because the amplitude of the refracted wave may be small compared to the amplitude of the ambient noise, the direct or refracted wave may be distorted because of scattering from heterogeneity, or the direct wave might be obscured by other waves associated with nonlinear deformation of the soil near the source. Because of these occasional difficulties, confidence in the traveltimes varies, and the confidence is classified as high, intermediate, low, or none. This classification is indicated by the colors used to plot the traveltimes (plate 3). Traveltimes with high

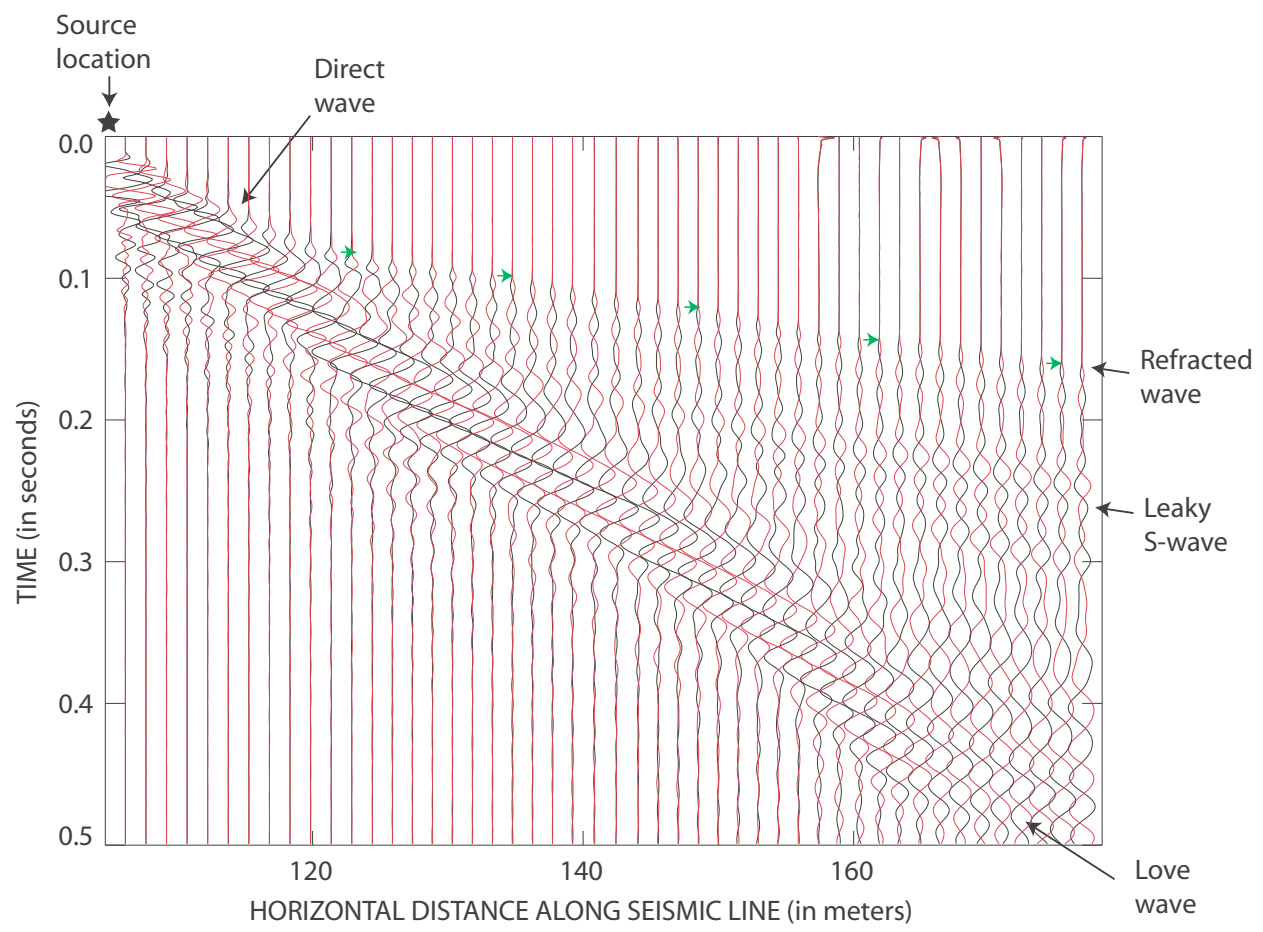

Figure 4. A typical example of seismic data. The seismograms recorded with one polarity of the source are red; the seismograms recorded with the opposite polarity are black. Several traveltimes for the refracted wave are indicated by the green arrows. 
confidences have an error that is estimated to be about $4 \mathrm{~ms}$. Of course, traveltimes with intermediate and low confidences have larger errors, although their magnitudes are not known. Picking the traveltimes and assigning the confidences were performed with a computer program similar to that developed by Ellefsen (2002).

To process the traveltimes along a seismic line, a geologic cross section was made, and $S$-wave velocities were assigned to every area within the cross section (plate 3 ). The traveltimes for every geophone were calculated using a finite-difference solution of the eikonal equation (Podvin and Lecomte, 1991); the solution was three-dimensional and properly accounted for the three-dimensional locations of the sources and receivers. The calculated traveltimes were compared to the picked traveltimes, and the differences (residuals) were used to determine where the cross section should be modified. This procedure was repeated until the important residuals were deemed small. Two ways were used to determine importance. First, the importance was equal to the confidence of the picked traveltime - that is, the importance could be high, intermediate, low, or none. Second, the importance was inversely proportional to the source-geophone distance, which is defined as the distance along the ground between a source and a geophone. Thus, the importance of the residual was high for small source-geophone distances and was low for moderate to large distances. After the processing, the magnitudes of most residuals were less than $8 \mathrm{~ms}$ (plate 3), although some were much larger. This issue is discussed later.

To develop a suitable cross section, a layer-stripping procedure usually worked well. First, the cross section had a single layer corresponding to the soil (or the mud in the former stream channel). After suitable velocities for the soil were determined, a second layer corresponding to the alluvium was added. After suitable thicknesses for the soil and velocities for the alluvium were determined, a third layer corresponding to bedrock was added. Finally, the velocities of bedrock were determined. The selection of the cross section was constrained in two ways: first, the cross section had to match the depths to the bedrock determined by drilling. That is, where a drill hole was close to a cross section (plate 1), the depth from the ground surface to bedrock determined by drilling had to match that in the cross section. Second, where two cross sections intersected (for example, $\mathrm{AA}^{\prime}$ and $\mathrm{BB}^{\prime}$ on plate 1), the corresponding layers and velocities had to be similar.

\section{Interpretation}

In the five cross sections (plate 3), the thickness of the topsoil ranges from 1.0 to $2.0 \mathrm{~m}$, with a median of 1.5 $\mathrm{m}$. (These statistics, as well as similar statistics that will be presented later, were computed from samples of the cross sections, samples that were spaced $25 \mathrm{~m}$ apart.) The thickness of the topsoil in the cross sections usually matches either the thickness of soil in the geologic logs (drill hole 4) or the combined thickness of the soil and an underlying silt and clay layer in the geologic logs (drill holes 1, 3, 3A, and 7). In the latter case, the $S$-wave refraction data were unable to differentiate between the soil and the underlying silt and clay layer. The aforementioned matches are satisfying because information on the thickness was not used in the processing. In the cross sections, the $S$-wave velocity of the topsoil ranges from 70 to $150 \mathrm{~m} / \mathrm{s}$, with a median of $100 \mathrm{~m} / \mathrm{s}$. Such velocities are consistent with $S$-wave velocities for soil reported by other investigators (Kudo and Shima, 1981; Suyama and others, 1986). Variations in the velocity are probably related to variations in the properties of the soil itself.

In the five cross sections (plate 3), the thickness of the alluvium ranges from 2.8 to $8.1 \mathrm{~m}$, with a median of 5.7 $\mathrm{m}$. The $S$-wave velocity ranges from 275 to $450 \mathrm{~m} / \mathrm{s}$, with a median of $350 \mathrm{~m} / \mathrm{s}$. Such velocities are consistent with $S$ wave velocities for alluvium reported by other investigators (Kudo and Shima, 1981; Meissner and others, 1985; Suyama and others, 1986). In cross section $\mathrm{BB}^{\prime}$, the velocities of the alluvium are 350,400 , and $450 \mathrm{~m} / \mathrm{s}$ on the left side, middle, and right side, respectively; similar changes in the velocity of the alluvium are observed in the other cross sections. Such velocity changes are attributed to changes in the composition of the sediments because $S$-wave velocities of unconsolidated sediments are affected by amount of clay (Bonner and others, 1999 and 2001).

The $S$-wave velocities of the bedrock range from 550 to $750 \mathrm{~m} / \mathrm{s}$, with a median value of $675 \mathrm{~m} / \mathrm{s}$. The bedrock, except perhaps in two areas, is probably the Browns Park Formation, as reported in the geologic logs (plate 2). The two exceptions are the right (eastern) sides of cross sections $\mathrm{AA}^{\prime}$ and $\mathrm{CC}^{\prime}$, and these two are discussed later. The depth from the ground surface to the bedrock ranges from 4.2 to $9.2 \mathrm{~m}$, with a median value of $7.3 \mathrm{~m}$. The differences between the depths in the cross sections and those in the geologic logs range from 0.0 to 0.8 $\mathrm{m}$, with a median value of $0.6 \mathrm{~m}$. (The computation omitted the differences associated with drill holes 3 and 3A because their geologic logs do not show the bedrock (plate 2).) Such small differences were expected because the depth from the ground surface to the bedrock was a constraint in the processing.

Cross sections $\mathrm{AA}^{\prime}$ and $\mathrm{BB}^{\prime}$ include three former stream channels that are filled with mud. The locations of these stream channels in the cross sections correspond exactly with the locations in the aerial photograph (plate 1). The $S$-wave velocities of the mud are 50,60, and $70 \mathrm{~m} / \mathrm{s}$, which is low compared to the previously mentioned velocities for soil and alluvium.

\section{Discussion}

\section{Traveltime Residuals}

Even though the magnitudes of most residuals are usually less than $8 \mathrm{~ms}$, the magnitudes of some residuals are larger 
than $8 \mathrm{~ms}$ and exceed this threshold over a significant portion of their associated spread (plate 3). (A residual is defined as the calculated traveltime minus the picked traveltime.) These anomalous intervals are of three types. The first type has large, negative residuals (that is, residuals less than $-10 \mathrm{~ms}$ ) and is found in spread $\mathrm{C} 1$ between 128.9- and 152.8-m horizontal distance, in spread C2 between 45.0- and 105.0-m horizontal distance, and in spread E2 between 128.8- and 160.4-m horizontal distance. For each of these three instances, the source was at end of the spread, far from the geophones (fig. 3A). The cause of these three anomalous intervals is unknown.

The second type of anomalous interval has moderately large, positive residuals (that is, residuals between about 7 and $10 \mathrm{~ms}$ ) and is found in spread D1 between 365.8- and 398.8-m horizontal distance, spread D2 between 256.5- and 283.4-m horizontal distance, spread D2 between 306.0- and 326.9-m horizontal distance, and spread D3 between 184.4- and 202.4$\mathrm{m}$ horizontal distance. Again, for each of these three instances, the source was at end of the spread, far from the geophones. The likely cause of these four anomalous intervals is weathering of the bedrock (see Field Site section). Weathering probably is greatest at the top of the bedrock and decreases with depth, and so the velocity probably is lowest at the top of the bedrock and increases with depth. Thus, for those geophones that are far from a source, the recorded wave probably propagated through deep, high-velocity bedrock, making the picked traveltimes less than the calculated traveltimes.

The third type of anomalous interval has large, positive residuals (that is, residuals greater than about $10 \mathrm{~ms}$ ) and is found in spread A1 between 394.1- and 455.5-m horizontal distance and in spread C1 between 109.4- and 164.9-m horizontal distance. For each anomalous interval, the source was at the eastern end of the spread, near the boundary between the alluvium and the Precambrian rocks (plate 1). The likely cause of the anomalous intervals is a change in the bedrockperhaps, the bedrock is Precambrian rock, or a thin layer of the Brown Park Formation overlying Precambrian rock, or terrace gravels (fig. 1). The first and second scenarios are attractive because the Precambrian rock, which is comprised of igneous and metamorphic rocks, probably has higher $S$-wave velocities than the Browns Park Formation, which is comprised of sedimentary rocks (see, for example, Bonner and Schock, 1989). The high velocities would cause the $S$-waves to arrive early, making the residuals large and positive. On the other hand, the third scenario-bedrock consisting of terrace gravels-is attractive because it is consistent with the geologic logs from drill holes 3 and $3 \mathrm{~A}$, which indicate that dense cobbles are in these two holes. For this particular scenario, the terrace gravels must have a high $S$-wave velocity. To determine which, if any, of the three scenarios is correct would require drilling or excavation.

\section{Ambiguity of Cross Sections}

Although each layer in each cross section (plate 3) has a specific thickness and velocity, a reasonable question is whether there is any ambiguity in thickness, velocity, or both. This ambiguity is analyzed using that portion of cross section DD' associated with spread D2 and using the traveltimes from one source (fig. 5). The properties of the alluvium were modified in three different ways. For the first modification, both the thickness and the velocity of the alluvium were decreased; for the second, both the thickness and the velocity of the alluvium were increased (fig. 5). For both modifications, the calculated traveltimes match the picked traveltimes almost as well as they do for the original cross section. The implication of this result is that there is some ambiguity in determining both the thickness and velocity of the alluvium. Nonetheless, the ambiguity in the thickness can be reduced if the cross section incorporates independent information about the geology; indeed, during processing, the thickness of the alluvium was constrained by the thickness obtained from geologic logs.

For the third modification of the alluvium (fig. 5), its constant velocity was replaced by a velocity that increased linearly with depth. That is, the modified velocity was 275 $\mathrm{m} / \mathrm{s}$ at the top of the alluvium, and it increased linearly with depth so that it was $350 \mathrm{~m} / \mathrm{s}$ at the bottom of the alluvium. This velocity function is a rough approximation to the velocity functions observed by Hunter (1998) and Bachrach and others (2000). For this modification, the calculated traveltimes match the picked traveltimes almost as well as they do for the original cross section (fig. 5). The implication of this result is that there is some ambiguity in determining whether the velocity of the alluvium is constant or increases linearly with depth. This ambiguity could be reduced if there were independent information about the velocity, such as velocity measurements from a surface-to-borehole survey.

\section{Findings and Practical Implications}

The focus of this investigation is to evaluate how well alluvium could be characterized with an $S$-wave refraction survey. In this regard, there are three significant findings. In cross section DD' (plate 3), for example, the five regions interpreted as alluvium are homogeneous. However, the geologic logs for drill holes 1 and 9 show that the alluvium is heterogeneous - that is, the alluvium consists of layers, which are silts and clays, or sands, or sands and gravels. Comparisons for the other cross sections and their associated geologic logs (plate 3) lead to the same observation. Thus, the first finding is that the layering within the alluvium could not be delineated with the $S$-wave refraction method.

In cross section $\mathrm{DD}^{\prime}$ (plate 3), for example, the five regions interpreted as alluvium show that the velocity of the alluvium changes significantly along the section. Examination of the other four cross sections leads to the same observation. The likely reason for these changes is that the composition of the sediment changes, but this hypothesis was not investigated because it would require additional work beyond the scope of the project. Thus, the second finding is that the $S$-wave refrac- 


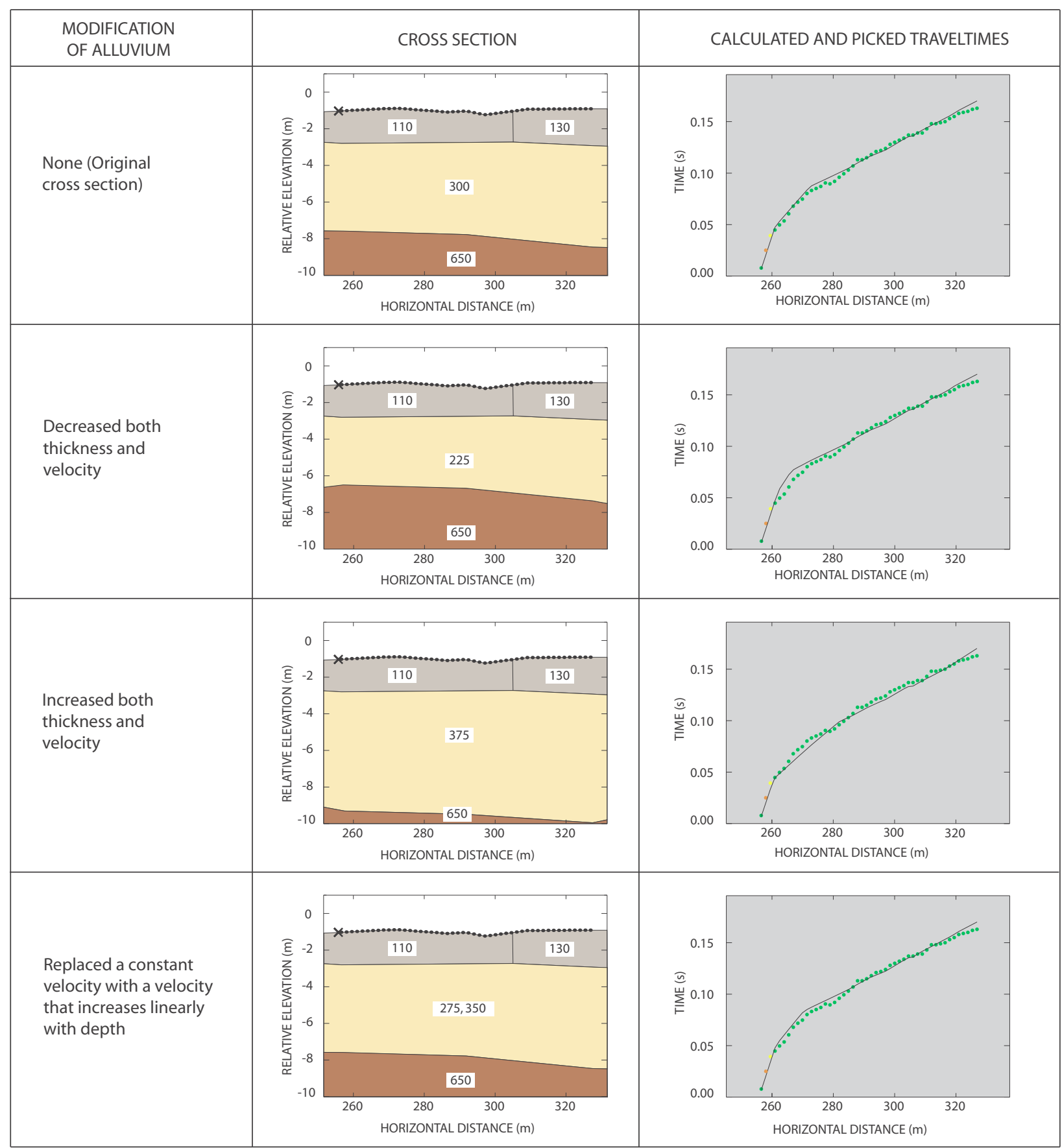

\begin{tabular}{|c|c|c|c|c|}
\hline \multicolumn{5}{|l|}{ Explanation } \\
\hline & & Source location & - & Picked traveltime, high confidence \\
\hline Topsoil & & Geophone location & 0 & Picked traveltime, intermediate confidence \\
\hline Alluvium & & $\begin{array}{l}\text { S-wave velocity }(\mathrm{m} / \mathrm{s}) \text { of a region } \\
\text { with a constant velocity }\end{array}$ & - & Picked traveltime, low confidence \\
\hline Bedrock & 275,350 & $\begin{array}{l}\text { S-wave velocities }(\mathrm{m} / \mathrm{s}) \text { at the top } \\
\text { and the bottom of a region whose } \\
\text { velocity increases linearly with } \\
\text { depth }\end{array}$ & 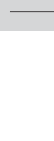 & Calculated traveltime \\
\hline
\end{tabular}

Figure 5. Ambiguity in determining the thickness and the velocity of the alluvium. The cross section is extracted from cross section DD', near spread D2. 
tion method may be able to map large-scale changes in the composition of alluvium.

Because there is a trade-off between the thickness and the velocity of the alluvium (see Ambiguity of Cross Sections section and fig. 5), the thickness cannot be accurately estimated using only $S$-wave refraction data. However, if additional geologic information (for example, drill-hole data) is incorporated as a constraint during processing, then the thickness can be accurately estimated. Thus, the third significant finding is that, to estimate the thickness of the alluvium, the $S$-wave refraction method must be used in conjunction with other geologic methods. This finding is particularly important because the thickness affects estimates of aggregate reserves.

Most of the useful geologic information about this field site was obtained from the drill holes, not from the $S$-wave refraction survey, because the geology here was simple. However, at other sites where the geology is complex and the drilling is difficult, we believe that useful geologic information could be obtained with $S$-wave refraction surveys. In this case, the refraction surveys should be conducted in conjunction with other characterization techniques such as drilling and perhaps other types of geophysical surveys.

\section{Acknowledgments}

John Hickman of the Lafarge Corporation taught us why geophysical surveys are important for assessing aggregate deposits and gave us the chance to test various methods at other sites in Colorado. Bruce Daniel of the Lafarge Corporation coordinated access to the field site. William Langer of the U.S. Geological Survey helped us develop the Cooperative Research and Development Agreement and guided us on its implementation. Jared Abraham, Roy George, and Carl Stoddard of the U.S. Geological Survey helped us collect the seismic data. The Mineral Resources Program of the U.S. Geological Survey funded this project.

\section{References}

Aki, K., and Richards, P.G., 1980, Quantitative seismology, theory and methods, volumes 1 and 2: San Francisco, W.H. Freeman and Co., 932 p.

Auton, C.A., 1992, The utility of conductivity surveying and resistivity sounding in evaluating sand and gravel deposits and mapping drift sequences in northeast Scotland: Engineering Geology, v. 32, p. 11-28.

Bachrach, R., Dvorkin, J., and Nur, A.M., 2000, Seismic velocities and Poisson's ratio of shallow unconsolidated sands: Geophysics, v. 65, no. 2, p. 559-564.
Barnett, A., and Ellefsen, K.J., 2000, Assessment of the alluvial sediments in the Big Thompson River valley, Colorado: U.S. Geological Survey Digital Data Series, DDS-66.

Bonner, B.P., and Schock, R.N., 1989, Seismic wave velocity, in Touloukian, Y.S., Judd, W.R., and Roy, R.F., eds., Physical properties of rocks and minerals: New York, Hemisphere Publishing Corp., p. 221-256.

Bonner, B.P., Berge, P.A., Aracne-Ruddle, C., Boro, C., Hardy, E., and Trombino, C., 1999, Ultrasonic characterization of synthetic soils for application to near surface geophysics, in Powers, M.H., Cramer, L., and Bell, R.S., eds., Proceedings of the Symposium on the Application of Geophysics to Engineering and Environmental Problems, 14-18 March 1999: Oakland, Calif., Environmental and Engineering Geophysical Society, p. 455-463.

Bonner, B.P., Berge, P.A., and Wildenschild, D., 2001, Compressional and shear wave velocities for artificial granular media under simulated near surface conditions, in Expanded Abstracts of the Technical Program with Author's Biographies: Society of Exploration Geophysicists, 71st Annual International Meeting and Exposition, 9-14 September 2001, San Antonio, Tex., p. 1419-1422.

Buffler, R.T., 1967, Browns Park Formation and its relationship to the late Tertiary geologic history of the Elkhead region, northwestern Colorado-south central Wyoming: Berkeley, University of California, Ph.D. thesis, 175 p., pl. 1, scale 1:125,000.

Crimes, T.P., Chester, D.K., Hunt, N.C., Lucas, G.R., Mussett, A.E., Thomas, G.S.P., and Thompson, A., 1994, Techniques used in aggregate resource analysis of four areas of the UK: Quarterly Journal of Engineering Geology, v. 27, part 2, p. 165-192.

Ellefsen, K.J., Lucius, J.E., and Fitterman, D.V., 1998, An evaluation of several geophysical methods for characterizing sand and gravel deposits: U.S. Geological Survey OpenFile Report 98-221, 26 p.

Ellefsen, K.J., Lucius, J.E., and Fitterman, D.V., 1999, Geophysics in exploration for sand and gravel, in Johnson, K.S., ed., Proceedings, 34th Forum on the Geology of Industrial Minerals, 2-6 May 1998, Norman, Oklahoma: Oklahoma Geological Survey Circular 102, p. 147-149.

Ellefsen, K.J., and Barnett, A., 2001, An investigation of alluvial sediments using $S$-wave refraction: A case study, in Proceedings of the Symposium on the Application of Geophysics to Engineering and Environmental Problems, 4-7 March 2001, Denver, Colo.: Environmental and Engineering Geophysical Society, [no page numbers], CD-ROM. 
Ellefsen, K.J., 2002, pick_sw: A program for interactive picking of $S$-wave refraction data, version 2.00: U.S. Geological Survey Open-File Report 02-176, available at http: //pubs.usgs.gov/of/2002/ofr-02-0176/.

Hasbrouck, W.P., 1983, Sketches of a hammer-impact, spikedbase, shear-wave source: U.S. Geological Survey Open-File Report 83-917, 7 p.

Hunter, J.A, 1998, Shear wave velocity measurements for earthquake hazards studies, Fraser River delta, British Columbia, in Bell, R.S., Powers, M.H., and Larson, T., eds., Proceedings of the Symposium on the Application of Geophysics to Engineering and Environmental Problems, 22-26 March 1998, Chicago, Ill., Environmental and Engineering Geophysical Society, p. 459-469.

Jacobson, R.P., 1955, Geophysical case history of a commercial gravel deposit: Mining Engineering, v. 7, p. 158-162.

Jol, H.M., Parry, D., Smith, D.G., 1998, Ground penetrating radar: Applications in sand and gravel exploration, in Bobrowsky, P.T., ed., Aggregate resources: A global perspective: Rotterdam, A.A. Balkema, Inc., p. 295-306.

Kudo, K., and Shima, E., 1981, Attenuation of shear waves in soil, in Toksöz, M.N., and Johnston, D.H., eds., Seismic wave attenuation: Tulsa, Okla., Society of Exploration Geophysicists, p. 325-338.

Kucera, R., 1962, Geology of the Yampa district, northwest Colorado: Boulder, University of Colorado, Ph.D. thesis, 675 p., pl. 1, scale 1:24,000.

Madole, R.F., 1991, Surficial geologic map of the Steamboat Springs $30^{\prime} \times 60^{\prime}$ quadrangle, Grand, Jackson, and Routt Counties, Colorado: U.S. Geological Survey Miscellaneous Investigations Series Map I-1825, scale 1:100,000.

McLamore, V.R. Anderson, D.G., and Espana, C., 1978, Crosshole testing using explosive and mechanical energy sources: Dynamic geotechnical testing, ASTM STP 654, American Society for Testing and Materials, p. 30-55.

Meissner, R., Stümpel, H., and Theilen, F., 1985, Shear wave studies in shallow sediments, in Dohr, R., ed., Handbook of geophysical exploration, Section 1, Seismic exploration; Volume 15, Seismic shear waves; Part B, Applications: London, Geophysical Press Limited, p. 224-253.

Middleton, R.S., 1977, Ground and airborne geophysical studies of sand and gravel in the Toronto region: Ontario Geological Survey Study GS18, 37 p.

Odum, J.K., and Miller, C.H., 1988, Geomorphic, seismic, and geotechnical evaluation of sand and gravel deposits in the Sheridan, Wyoming, area: U.S. Geological Survey Bulletin 1845,32 p.
Podvin, P., and Lecomte, I., 1991, Finite difference computation of traveltimes in very contrasted velocity models: A massively parallel approach and its associated tools: Geophysical Journal International, v. 105, p. 271-284.

Satô, Y., 1952, Study on surface waves IV., Generation of Love- and other type of $\mathrm{S}_{\mathrm{h}}$-waves: Bulletin of the Earthquake Research Institute [Tokyo], v. 30, p. 101-120.

Saarenketo, T., and Maijala, P., 1994, Applications of geophysical methods to sand, gravel and hard rock aggregate prospecting in northern Finland, in Lüttig, G.W., 1994, Aggregates-Raw Materials Giant: Report on the 2nd International Aggregates Symposium, Erlangen, Germany, October 22-27, 1990, p. 109-123.

Singhroy, V.H., and Barnett, P.J., 1984, Locating subsurface mineral aggregate deposits from airborne infrared imagery (reflected and thermal): A case study in southern Ontario: Proceedings of the International Symposium on Remote Sensing of Environment, 3rd Thematic Conference: Remote Sensing for Exploration Geology, p. 523-539.

Snyder, G.L., 1980, Geologic map of the northernmost Gore Range and southernmost northern Park Range, Grand, Jackson, and Routt Counties, Colorado: U.S. Geological Survey Miscellaneous Investigations Series Map I-1114, scale 1:48,000.

Subcommittee of the SEG Engineering and Groundwater Geophysics Committee, Pullan, S.E., Chairman, 1990, Recommended standard for seismic (/radar) data files in the personal computer environment: Geophysics, v. 55, no. 9, p. 1260-1271.

Suyama, K., Imai, T., Ohtomo, H., Ohta, K., and Takahashi, T., 1986, Delineation of structures in alluvium and diluvium using $S H$-wave reflection and VSP methods, in Danbom, S.H., and Domenico, S.N., eds., Shear-wave exploration: Tulsa, Okla., Society of Exploration Geophysicists, p. $165-179$.

Timmons, B.J., 1995, Prospecting for natural aggregates: An update: Rock Products, v. 98, no. 1, p. 31-37.

Tweto, O., 1976, Geologic map of the Craig $1^{\circ} \times 2^{\circ}$ quadrangle, northwestern Colorado: U.S. Geological Survey Miscellaneous Investigations Series Map I-972, scale 1:250,000.

Wilcox, S.W., 1944, Sand and gravel prospecting by the earth resistivity method: Geophysics, v. 9, p. 36-46.

Published in the Central Region, Denver, Colorado

Manuscript approved for publication January 21, 2005

Editing, page layout, photocomposition-Richard W. Scott, Jr. 508 compliance-Amber Hess

Webmaster-Tracy A. Pinto

Graphics prepared by the authors 